\title{
DISKRIMINASI PADA PRIA BERGAYA FEMININ
}

Oleh:

\section{RESI YULIA, YUSUARSONO, ANIS ENDANG SM \\ Program Studi Ilmu Komunikasi Fakultas Ilmu-Ilmu Sosial Unived Bengkulu}

\begin{abstract}
This study aimed to find out the discrimination in feminine men in Sawah Lebar, Bengkulu. Discrimination occured because people only recognize two sexes, the female and male. In society, gender differences had not only biological implications, but also social and psychological because people have different expectations on the attitude, behavior, and appearance between women and men.This research used a qualitative descriptive approach. Informants were taken by using purposive sampling method. Data were collected by using interview, observation and documentation techniques. The results showed a picture of discrimination as evidenced by marginalization, subordination, stereotyping, violence, and double burden among the feminine men in society.
\end{abstract}

Keywords: discrimination, feminine men, gender differences

\section{PENDAHULUAN}

Manusia dilahirkan ada dua jenis kelamin pria dan wanita, hanya dengan melihat genital fisiknya manusia dapat mengetahui dengan jelas identitas gendernya sebagai pria atau wanita. Namun, terdapat sekelompok manusia yang terjebak didalam tubuh yang salah, dikarenakan sekelompok manusia tersebut merasa sebagai anggota jenis kelamin yang berlawanan dengan genital fisiknya misalnya ketika seorang pria merasa teperangkap dalam tubuh wanita, atau sebaliknya seorang wanita teperangkap dalam tubuh pria.

Selain berimplikasi biologis perbedaan jenis kelamin berimplikasi pada perbedaan psikologis dan sosiologis, Dalam hal ini masyarakat memberikan ekspektasi yang berbeda terhadap perempuan dan laki-laki, perempuan dituntut untuk berperilaku feminin seperti berbicara dan berperilaku lembut,pasif, bersikap sopan dan kemayu, menggunakan make up, berjalan dengan pelan-pelan dan lebih menggunakan perasaan. Sedangkan lakilaki diekspektasikan untuk memiliki karakter dan berperilaku maskulin seperti berotot, suka berpetualang, lebih mengedepankan logika, aktif dan berani mengambil resiko.

Seorang laki-laki sering dianggap sebagai pelindung perempuan karena secara fisik lebih kuat. Tetapi, sebenarnya cukup banyak laki-lakiyang memiliki sifat feminin, atau populer disebut "kemayu". Pria yang masuk kategori ini sering dipandang lebih rendah dibandingkan dengan pria jantan. Seorang pria dianggap jantan jika ia memiliki postur tubuh tinggi, tegap, kekar, kuat dan berperilaku maskulin.

Kesalahan tubuh ini dianggap tidak normal kerena itu mereka mendapat perlakuan diskriminatif, diperlakukan tidak sewajarnya. Diskriminasi yang dilakukan banyak melalui media seperti meme yang menyebar secara viral 
dimedia-media sosial seperti instagram, facebook dan twitter. Bentuk diskriminasi lainnya yang dapat dilihat dalam komentar-komentar pedas dimedia sosial, seperti kata-kata untuk tidak layak hidup, dan manusia jadijadian yang menyertai atau mengomentari gambar-gambar tersebut.

Diskriminasi yang dilakukan dimedia-media sosial terhadap pria-pria "kemayu" atau feminin juga terjadi dalam dunia nyata. Pria-pria feminin dalam pandangan masyarakat seringkali dijadikanbahan bercandaan atau ejekan, misalnya dari segi gaya bicara, cara berjalan, berpenampilan atau cara duduk. Ideologi patriarki sangat mengedepankan kepentingan laki-laki, meninggikan nilai-nilai maskulin dan pada saat yang sama mengebelakangkan kepentingan perempuan dan merendahkan nilai feminin karena nilai-nilai maskulin dianggap lebih tinggi. Perempuan yang maskulin cenderung lebih diterima dari pada laki-laki yang feminin. Hal ini dapat dilihat, ketika laki-laki merasa tersinggung saat mereka disebut "cerewet seperti perempuan" atau "lebai seperti perempuan" dan sebagainya. seperti pria yang suka berbicara berlebihan ketika mereka terlihat sesekali berkumpul bersama masyarakat. Mulai dari sinilah diskriminasi terhadap pria bergaya feminin.

Hal yang demikian seharusnya tidak terjadi, karena sesungguhnya manusia berhak berperilaku sesuai dengan keinginannya dan tidak mendapatkan perlakuan diskriminatif. Di Indonesia, aturan yang menentang perlakuan diskriminatif dituangkan dalam Undang-undang 1945Amademen pasal 28 i ayat 2 yang berbunyi :"Setiap orang berhak bebas dari perlakuan yang bersifat diskriminasi atas dasar apapun dan berhak mendapat perlindungan terhadap perlakuan yang diskriminatif".
Selain itu, sejak tahun 1999 warga Indonesia telah mendapat jaminan perlindungan yang disahkan kedalam UU No 39/1999 tentang Hak Asasi Manusia. Pasal 3 ayat (2) Undang-undang tersebut menyebutkan "Setiap orang atas pengakuan, jaminan, perlindungan dan perlakuan hukum yang adil serta mendapat kepastian hukum dan perlakuan yang sama didepan hukum" dan ayat (3) berbunyi, "setiap orang berhak atas perlindungan hak asasi manusia dan kebebasan dasar manusia, tanpa diskriminasi".

Seharusnya kesalahan tubuh pada pria-pria feminin ini tidak dijadikan alasan untuk melakukan diskriminasi karena mereka tak dapat menentukan jenis tubuh sesuai yang mereka kehendaki. Dalam rubrik Health laman kompas.com tanggal 30 januari 2016, dr. Roslan Yusni Hasan, Sp.Bs menyebut bahwa pria dapat memiliki sifat dominan feminin karena terjadinya polarisasi, yaitu penarikan hormon $\mathrm{X}$ maskulin oleh kromosom Y. Jika penarikan ini terjadi secara ekstrim, maka sisi maskulin akan munculdengan jelas. Sebaliknya jika ekspresi gen hanya terjadi setengah, seseorang berjenis kelamin laki-laki akan memiliki ciri feminin. Disebutkan oleh dr. Roslan kuat tidaknya polarisasi ini tidak dapat ditentukan karena terjadi dengan sendirinya atau diluar kendali manusia.

Berdasarkan observasi awal, di kelurahan Sawah Lebar tepatnya Jl. Kemang Manis 4 RT RW 2 kota Bengkulu, penulis menemukan pria bergaya feminin yang terlihat dari cara berpakaian, cara berjalan dan cara makan. Kecenderungan yang lebih menyerupai perempuan ini sering dijadikan sebagai bahan tertawaan dalam lingkungan. Diskriminasi yang sering terjadi di Sawah Lebar Jalan Kemang Manis 4 RT 7 RW 2 ini seperti perkataan yang dilontarkan oleh masyarakat kepada 
pria bergaya feminin misalnya "kamu tidak akan sama seperti orang lain jika gaya kamu seperti ini (kemayu)". Kekerasan fisik pun sering terjadi pada pria bergaya feminin ketika mereka melakukan keributan antar sesamanya, namun menimbulkan keresahan di masyarakat karena sering berbicara dengan nada keras dan kalau ada masalah pertengkaran terjadi di hadapan masyarakat. Bagi masyarakat yang melihat, merasa terganggu dengan hal tersebut. Hal inilah yang membuat kekerasan fisik terjadi, baik dari sesama temannya maupun dari masyarakat yang kesal hingga pernah memukul mereka.

Selain itu, dalam kehidupan sehari-hari, pria-pria bergaya feminine tidak mendapatkan kebebebasan untuk secara bebas menampilkan diri dan mengungkapkan identitas sesuai keinginan mereka. Ketika ada kegiatan di lingkungan tempat tinggal, contohnya dalam acara perlombaan 17 Agustus mereka tidak dipercayai untuk menjadi panitia acara ataupun untuk sekedar mengikuti lomba-lomba yang ada. Hal ini terjadi karena mereka dianggap tidak cukup mampu mengikuti perlombaan untuk para laki-laki seperti panjat pinang dan tarik tambang, dan mereka adalah sosok laki-laki untuk mengikuti perlombaan-perlombaan yang diperuntukkan untuk perempuan. Berangkat dari hal tersebut, penulis tertarik untuk melakukan penelitian berjudul "Diskriminasi pada Pria Bergaya Feminin di Kelurahan Sawah Lebar, tepatnya Jl. Kemang Manis 4 RT. 7 RW. 2 Kota Bengkulu". Adapun Jl. Kemang Manis 4 dipilih sebagai lokasi penelitian karena dari hasil pra penelitian, jumlah pria bergaya feminin di daerah ini cukup tinggi, yaitu sekitar 13 orang.

\section{METODE PENELITIAN}

Penelitian ini menggunakan pendekatan kualitatif. Disebutkan Moleong (2007) penelitian jenis ini bertujuan untuk memahami fenomena yang dialami oleh subjek penelitian seperti perilaku, persepsi, motivasi, dan tindakan. Lebih lanjut dikatakan Moleong, penelitian kualitatif menghasilkan data deskriptif berupa kata-kata tertulis atau lisan dari orangorang dan perilaku yang dapat diamati.

Dalam penelitian ini, informan dibagi kedalam dua kelompok, yaitu informan pokok dan informan kunci. Informan pokok terdiri dari anggota masyarakat yang tinggal di wilayah pria bergaya feminine. Sedangkan informan kunci merupakan pria bergaya feminin di Sawah Lebar Jl. Kemang Manis 4 RT 7 RW 2 Kota Bengkulu. Berikut merupakan tabel jumlah informan penelitian.

Tabel 1 Informan pokok penelitian

\begin{tabular}{|c|c|c|c|c|}
\hline No & Nama & $\begin{array}{c}\text { Jenis } \\
\text { Kelamin }\end{array}$ & Umur & Pekerjaan \\
\hline 1 & NV & Laki-Laki & 24 & Mahasiswa \\
\hline 2 & EKL & Laki-Laki & 27 & Mahasiswa \\
\hline 3 & UJ & Laki-Laki & 24 & Mahasiswa \\
\hline 4 & TN & Laki-Laki & 25 & Mahasiswa \\
\hline
\end{tabular}

Sumber: data penelitian, 2016

Tabel 2 Informan kunci penelitian

\begin{tabular}{|c|c|l|l|l|}
\hline No & Nama & $\begin{array}{c}\text { Jenia } \\
\text { Kelamin }\end{array}$ & Umur & Perkerjaan \\
\hline 1 & MH & Laki-Laki & 40 & Ketua RT \\
\hline 2 & LH & Laki-Laki & 35 & $\begin{array}{l}\text { Tokoh } \\
\text { Bidang } \\
\text { Agama }\end{array}$ \\
\hline 3 & SR & Laki-Laki & 47 & Wiraswasta \\
\hline 4 & HH & Laki-Laki & 45 & Wiraswasta \\
\hline
\end{tabular}

Sumber: data penelitian, 2016

$$
\text { Data dalam penelitian }
$$

dikumpulkan dengan tiga teknik, yaitu observasi, wawancara, dan dokumentasi. Sedangkan teknik analisa data dilakukan 
menurut langkah-langkah berikut Miles dan Huberman (1994):

1. Pengumpulan data

2. Reduksi data

3. Penyajian data

4. Penarikan kesimpulan

\section{HASIL PENELITIAN DAN PEMBAHASAN \\ Hasil Penelitian}

\section{Marginalisasi}

Marginalisasi

dijelaskan

Vaughan dan Hogg (2005) sebagai penyingkiran pada masyarakat, baik dalam bidang ekonomi, budaya, sosial, politik, dan hukum. Berkaitan dengan diskriminasi, berikut hasil wawancara dengan pria-pria bergaya feminine sebagai berikut. NV (24) mengatakan:

"...kalau menurut ambo perlakuan yang cak mano dulu kalau perlakuan baik dak apolah kalau idak baik marah lah aku" (wawancara tanggal 1 April 2016)

Sedangkan menurut EKL (27):

$$
\text { “...yak tergantung }
$$
perlakuannyo dulu baik apo idak" (wawancaara tanggal 15 April 2016)

Kemudian dikatakan UJ (24):

$$
\begin{aligned}
& \text { "...biaso ajaolah kalau } \\
& \text { perlakuannyo sewajarnyo" } \\
& \text { (wawancara tanggal } 16 \text { April } \\
& \text { 2016) }
\end{aligned}
$$

Sedangkan menurut TN (25):

“...tergantung perlakuannyo cakmano dulu baik apo idak law baik dak ngapo kalau idak baik aku dak menerima" (wawancara 20 April 2016)

Berdasarkan dari hasil wawancara dengan pria bergaya feminin mengenai perlakuan terhadap pria bergaya feminin diatas, dapat disimpulkan bahwa tidak semua masyarakat melakukan diskrimanasi terhadap pria bergaya feminin. Dalam wawancara berikutnya didapatkan hasil sebagai berikut. NV (24) mengatakan:

“...yo emang aku sendiri merasokannyo dikucilkan masyarakat tapi dak apolah yang penting aku senang dengan hidup ku cak iko karno aku lebih senang cak iko" (wawancara tanggal 1 April 2016)

Sedangkan EKL (27) menyatakan bahwa:

“... idak jugo sih kalau ambo karno ambo idak terlalu sering gabung kek orang ambo enak yo dewek ajo" (wawancara tanggal 15 April)

Kemudian menurut UJ (24): “...yo tapi biarlah ambo dak ngijo itu, ambo sering dikucilkan tu pas ado kegiatan" (wawancara tanggal 16 April)

Sedangkan menurut TN (25):

“...yo pernah ambo dikucilkan tapi masa bodoh ajo ambo endak bekwan kek ambo pelah idak udem" (wawancara tanggal 20 April 2016)

Berdasarkan hasil wawancara mengenai penyingkiran terhadap pria bergaya feminin oleh masyarakat, ternyata mereka lebih cuek dan tidak menghiraukan perkataan masyarakat tentang mereka. Hal ini sesuai dengan hasil observasi peneliti bahwa pria bergaya feminin cenderung lebih cuek dan tidak menghiraukan perkataan masyarakat. Sedangkan menurut responden yang berasal dari anggota masyarakat yang tinggal di sekitar pria bergaya feminine, Bapak MH (40) mengatakan:

“...pria bergaya feminin suatu karakter yang terbentuk karena pergaulan yang lebih condong kelawan jenis, atau bawaan dari lahir yang lebih banyak mengambil gen ibunya" 
(Wawancara tanggal 30 Maret 2016).

Dalam wawancara yang dilakukan, Bapak LH (35), Bapak HH (45) dan Bapak SR (47) menyebutkan bahwa pria bergaya feminin tidak apa-apa asalkan tidak mengganggu norma dan masyarakat. Dikatakan Bapak LH (35):

"...sah-sah bae asalkan idak meresahkan masyarakat" (wawancara tanggal 3 April 2016)

Sedangkan Bapak SR (47) mengatakan: "...menurut sayo ajo asal idak menyimpang ajo dari norma-norma"

Berbeda dengan Bapak MH, LH, dan SR, Bapak HH (45) mengatakan:

“...menurut sayo pria bergaya feminin itu dak baik karno idak sesuai dengan jenis kelaminnyo" (wawancara tanggal 4 April 2016)

Berdasarkan hasil wawancara diatas diketahui bahwa pria bergaya feminin tidak terlalu disukai karena mereka telah melakukan "penyimpangan" dari jenis kelamin yang dibawanya sejak lahir. Sedangkan kaitannya dengan penerimaan masyarakat, berikut merupakan hasil wawancara dengan informan pokok. Bapak MH (40) menyatakan bahwa:

“...kalau sayo menerimonyo yak biaso ajo dak apolah asal jangan buat masalh di Kemang Manis ko" (wawancara tanggal 30 Maret 2016)

Sedangkan menurut Bapak LH (35) sebagai:

“...menerimo sih, tapi jangan bae buek masalah di Kemang Manis ko"(Wawancara tanggal 1 April 2016)

Berdasarkan menurut Bapak SR (47) sebagai berikut:

“...menerimo kalau sayo karno bagaimana pun tobo tu samolah cak koto sekedar beda ajo perilakunyo dan caronyo cak cewek $t u$ "

Kemudian menurut Bapak HH (45) sebagai berikut:

“...menerimo sih tapi jangan

buek masalah ajo cak ributribut"'(wawancara tanggal 4 April 2016)

Berdasarkan hasil wawancara dengan masyarakat dapat disimpulkan bahwa penerimaan pria bergaya feminin di Kemang Manis 4 cukup baik. Masyarakat mau menerima mereka asalkan mereka tidak membuat masalah atau kerusuhan di daerah tempat tinggal mereka. Hal ini diperkuat hasil observasi penulis yang menunjukkan badanya penerimaan bagi pria bergaya feminine untuk tinggal di daerah tersebut.

\section{Subordinasi}

Subordinasi adalah suatu penilaian bahwa peran yang dilakukan oleh satu jenis kelamin lebih rendah dari yang lain (Vaughan dan Hogg, 2005). Berkaitan dengan hal tersebut disampaikan beberapa pernyataan informan mengenai subordinasi. Pernyataan pertama disampaikan oleh NV (24) sebagai berikut:

"...yak biaso ajolah sayo idak peduli kecek orang tu yang njalaninyo kan kito" (wawancara tanggal 25 April 2016)

Sedangkan menurut EKL(27):

“...sebenarnyo sayo dak menerimo masyarakat nilai yang negatif itu tapi biarlah aku dak ngijo" (wawancara tanggal 10 April 2016)

Pernyataan senada juga disampaikan UJ (24) sebagai berikut:

"...biaso ajolah dak usah dengari orang"(wawancara tanggal 24 April 2016)

Hal yang sama juga disampaikan oleh TN (25) sebagai berikut: 
“...biarlah orang ngecek cak itu mintak makan kek tobo tu kito idak" (wawancara tanggal 27 April 2016).

Berdasarkan hasil wawancara pada pria bergaya feminin ternyata mereka lebih cuek dan tidak begitu mendengarkan perkataan masyarakat kepada mereka. Hal ini diperkuat observasi peneliti bahwa pria bergaya feminin ini tidak menghiraukan perkataan masyarakat tentang mereka.

Sedangkan menurut pria bergaya feminin mengenai jika masyarakat menyatakan pria bergaya feminin tidak bisa masuk kedalam organisasi. Pernyataan pertama oleh NV (24) sebagai berikut:

"biarlah situ ambo dak ngijo kecek masyarakat tu ambo dak mintak makan kek tobo tu' (wawancara tanggal 13 April 2016)

Sedangkan menurut EKL (27):

"biarlah situ orang endak ngecek apo" (wawancara tanggal 15 April 2016)

Senada juga yang disampaikan UJ ( 24) sebagai berikut:

"dak usah dihiraukan kecekan orang" (wawancara tanggal 16 April)

Sedangkan menurut TN (25) sebagai berikut:

"ambo dak pernah ngijo kecek an orang cak itu" (wawancara tanggal 16 April)

Berdasarkan wawancara pada pria bergaya feminin mengenai keikutsertaan pria bergaya feminin kedalam organisasi, ternyata mereka bersikap cuek dan tidak mendengarkan perkataan masyarakat yang menilai demikian. Hal ini diperkuat dengan observasi peneliti bahwa pria bergaya feminin lebih cendrung cuek dan tidak peduli perkataan masyarakat.

Sedangkan menurut responden masyarakat mengenai pria bergaya feminin melakukan pekerjaan layaknya seperti laki-laki, berikut pernyataan oleh para informan pokok. Bapak MH (40), selaku ketua RTKemang Manis 4 RT 7 RW 2 kota Bengkulu, mengatakan sebagai berikut:

“...kalau menurut sayo dio tu bisa tapi tergantung pria feminin tu lagi tapi yang banyak aku temui pria feminin tu banyak dak pacak karno takut panas"(wawancara pada tanggal 6 April 2016)

Sedangkan menurut Bapak LH (35) sebagai berikut:

“...pacak tapi banyak nyo pria feminin tu takut panas samo cak cewek jugo" (wawancara tanggal 8 April 2016)

Kemudian Bapak SR (47) menyatakan sebagai berikut:

"...pacaklah tapi tergantung pekerjaannyo apo dulu” (wawancara tanggal 9 April 2016)

Sedangkan menurut Bapak HH (47) sebagai berikut:

“...tergantung pekerjaannyo jugo sebenarnyo" (wawancara tanggal 10 2016)

Ternyata hasil wawancara dari masyarakat tergantung dengan pekerjaanya seperti apa. Hal ini sesuai dengan hasil observasi bahwa pria bergaya feminin untuk melakukan pekerjaan laki-laki kebanyakannya tidak bisa dan takut panas.

Para responden masyarakat menyatakan tentang bagaimana jika pria bergaya feminin dijadikan pemimpin dalam sebuah organisasi masyarakat. Pernyataan pertama disampaikan oleh Bapak MH (40) sebagai berikut:

"...yo dak apo asalkan dio pacak memimpin dengan baik" (wawancara tanggal 6 April 2016) 
Pernyataan berbeda disampaikan oleh Bapak LH (35) sebagai berikut:

"...aiii dak mungkin lah hidup nyo bae cak itu apo lagi endak mimpin" (wawancara tanggal 8 April 2016)

Kemudian menurut Bapak SR (47) sebagai berikut:

“...bisa ancur organisasi tu kalau pria feminin memimpinnyo karno hidupnyo bae lah dak benar apo lagi endak memimpin" (wawancara tanggal 9 April 2016)

Sedangkan Bapak HH (45) menyatakan berikut:

“...mendingan dak usah ado pemimpin law pria bergaya feminin endak mimpin nyo" (wawancara tanggal 10 2016)

Berdasarkan hasil wawancara penulis dengan masyarakat, didapati banyaknya masyarakat yang tidak mempercayai dan meyakini jika pria bergaya feminin ini akan memimpin suatu organisasi. Hal ini sesuai dengan hasil observasi penulis yang dikuatkan dengan hasil wawancara dari informan penelitian dan penjelasan bahwa pria bergaya feminin ini tidak dipercayai jadi seorang pemimpin.

\section{Streotip Negatif}

Stereotip merupakan pelabelan yang bersifat negatif. Kaitannya dengan label-label negative yang dilekatkan kepada pria bergaya feminine, dikatakan NV (24):

"...ambo keceki yak karno itu menyangkut hidup kito" (wawancara tanggal 20 April 2016)

Sedangkan pernyataan yang disampaikan oleh EKL (27) sebagai berikut:

"...aiii biarlah situ endak ngecek apo terserahlah situ" (wawancara tanggal 21 April 2016)
Kemudian pernyataan juga diungkapkan UJ (24) sebagai berikut:

“...dak ambo ngijo orang yang penting aku dapek duit hidup ambo senang" (wawancara tanggal 27 April 2016)

Sedangkan menurut TN (25) sebagai berikut:

“...biarlah dak usah dengarkan perkataan orang yang negatif tentang kito" (wawancara tanggal 26 April 2016)

Berdasarkan hasil dari wawancara pada pria bergaya feminin mereka lebih cuek dan tidak peduli apa yang dikatakan masyarakat terhadap mereka, karena merekalah yang menjalininya. Hal ini sesuai dengan hasil observasi bahwa pria bergaya feminin ini lebih cuek dan tidak menghiraukan apa yang dikatakan masyarakat.

Sedangkan menurut responden pria bergaya feminin mengenai jika ada masyarakat yang menyebut mereka sebagai banci. Pernyataan pertama NV (24) sebagai berikut:

“...yak terserah lah orang endak ngecek apo" (wawancara tanggal 17 April)

Senada yang diungkapkan oleh EKL (27) sebagai berikut:

“...kalau aku dak ngapik $i$ nyo orang cak itu karno aku dak mintak apo-apo kek orang tu" (wawancara tanggal 18 April 2016)

Sedangkan menurut UJ (24) sebagai berikut:

"...marahlah apo maksud ngecek cak itu cak dio elok ajo" (wawancara tanggal 18 April)

Sedangkan menurut TN (24) sebagai berikut:

"...biarlah dak usah dengar omongan orang" (wawancara tanggal 19 April)

Berdasarkan hasil wawancara pada pria bergaya feminin bahwa 
perkataan masyarakat yang mengatakan pria bergaya feminin itu banci mereka lebih cuek dan tidak terlalu menghiraukan perkataan masyarakat. Hal ini memperkuat hasil observasi bahwa pria bergaya feminin ini tidak terlalu menghiraukan perkataan masyarakat tentang mereka. Yang penting mereka senang menjalani kehidupan mereka.

Sedangkan menurut responden masyarakat terhadap penilaian negatif pada pria bergaya feminin, menurut Bapak MH (40) sebagai berikut:

"...menurut sayo penilaian
negatifnyo wajar ado, karno
kelakuan tobo tu idak sesuai
dengan jenis kelaminnyo"
(wawancara tanggal 12 April
2016)

Sedangkan Bapak LH (35) memberikan pernyataan sebagai berikut:

“...idak tau bapak karno idak pulo perhatikan nian yang aku tau dio tu cuma melentik ajo" (wawancara tanggal 13 April 2016)

Kemudian menurut Bapak SR (47) sebagai berikut:

"...seperti caronyo yang cak cewek" (wawancara tanggal 13 April 2016)

Sedangkan menurut Bapak HH (45) sebagai berikut:

"...biaso ajo orang cak itu tu
emang negatif terus"
(wawancara tanggal 13 April
2016)

Berdasarkan hasil dari beberapa pernyataan diatas dapat diperoleh pria bergaya feminin ini dalam masyarakat kelurahan Sawah Lebar jalan Kemang Manis 4 RT 7 RW 2 kota Bengkulu mendapat penilaian negatif dari masyarakat tentang banyaknya masyarakat yang tidak menyukai cara pria bergaya feminin. Hal ini sesuai dengan hasil observasi peneliti bahwa pria bergaya feminin ini lebih cenderung berperilaku seperti perempuan. Hal inilah yang menimbulkan penilaian negatif dari masyarakat terhadap pria bergaya feminin.

\section{Kekerasan}

Kekerasan dapat terjadi secara fisik dan non fisik. Menurut Vaughan dan Hogg (2005), kekerasan sering terjadi akibat ulah atau perilaku yang tidak baik, sehingga membuat keresahan di masyarakat sekitar. Berkaitan dengan hal tersebut, kekerasan sering terjadi pada pria bergaya feminin, beberapa pernyataan dari masyarakat mengenai kekerasan fisik tehadap pria bergaya feminin, pernyataan pertama yang disampaikan oleh NV (24) sebagai berikut:

"...tergantung kekerasannyo
apo dulu dan yang buek
masalah dulu siapo"
(wawancara tanggal 23 April
2016)

Sedangkan pernyataan EKL (27) sebagai berikut:

“...pernah ambo kan belago kek kawan ambo karno suaro kami ribut akhirnyo ibuk kos mukul ambo pakai sapu" (wawancara tanggal 24 April 2016)

Kemudian menurut UJ (24) sebagai berikut:

“...tergantung dulu apo

kekerasannyo dan siapo dulu yang buat masalnyo" (wawancara tanggal 23 April 2016)

Kemudian pernyataan TN (25) sebagai berikut:

“...sebenarnyo kekerasan tu dak boleh, cukup kasih tau ajo kesalahannyo ajo, ambo pernah jugo ditendang kek kawan ambo tapi ambo diam ajo karno ambo dak berani melawan, dio tu kuek nian" (wawancara tanggal 26 April 2016) 
Berdasarkan hasil wawancara pada pria bergaya feminin mengenai kekerasan yang sering terjadi pada pria bergaya feminin, mereka tidak menyetujui kekerasan itu ada karena bagaimana pun mereka sama seperti masyarakat lainnya. Hal ini sesuai dengan hasil observasi peneliti bahwa kekerasan fisik yang dialami pria bergaya feminin ini sering terjadi pada saat mereka membuat ribut sehingga terjadinya kekerasan yang dilakukan orang sekitarnya, seperti ibu kos tempat mereka tinggal.

Sedangkan menurut responden para pria bergaya feminin mengenai non fisik yang sering dilakukan oleh masyarakat, bagaimana menyikapi sindiran masyarakat pada pria bergaya feminin, menurut NV (24) sebagai berikut:

“...biaso ajo kalau menurut ambo, karno ambo dak mintak makan kek masyarakat jadi biarlah orang endak ngecek apo tobo tu ambo idak ambik pusing lah" (wawancara tanggal 23 April 2016)

Kemudian pernyataan yang sama diungkapkan oleh EKL (27) sebagai berikut:

“...ado sih, tapi ambo idak ngijo orang dak kan maju law endak dengar kecek orang terus tu'"(Wawancara tanggal 24 April 2016)

Kemudian pernyataan yang sama disampaikan oleh UJ (24) sebagai berikut:

“...sering tapi ambo idak ngijo orang biarlah situ mereka endak ngomongi ambo apo" (Wawancara tanggal 23 April 2016)

Sedangkan pernyataan yang disampaikan oleh TN (25) sebagai berikut:

“...pernah tapi ngapoi jugo dengari omongan orang yang njalaninyokan kito"

(wawancara tanggal 26 April 2016)

Berdasarkan hasil wawancara diatas ternyata pria bergaya feminin ini lebih cuek terhadap perkataan yang sering dilontarkan masyarakat terhadap mereka. Sedangkan hasil observasi penulis, masyarakat hal yang sama bahwa pria bergaya feminin ini tidak peka terhadap omongan orang tentang mereka.

Sedangkan menurut responden masyarakat mengenai kekerasan yang terjadi pada pria bergaya feminin ini, pernyataan pertama disampaikan oleh Bapak MH (40), sebagai berikut:

"...menurut sayo tergantung disudut mana yang dilakukan, kalau penyimpangan sosial jelas sayo setuju dengan perlakuan yang dilakukan masyarakat, tetapi jika perlakuan pria bergaya feminin tidak menyimpang normanorma sosial jelaslah sayo idak sependapat apa yang dilakukan masyarakat" (wawancara tanggal 14 April 2016)

Sedangkan pernyataan juga disampaikan Bapak LH (35) sebagai berikut:

"...kalau menurut sayo itu idak elok kekerasan terhadap pria bergaya feminin karno dio jugo manusio samo cak kito memiliki kekurangan dan kelebihan" (wawancara tanggal 14 April 2016)

Kemudian pernyataan yang diungkapkan Bapak SR (47) sebagai berikut:

"...kalau menurut sayo kekerasannyo tu kekerasan yang cakmano dulu dan aku jugo nengok kekerasannyo dulu cakmano" (wawancara tanggal 14 April 2016)

Sedangkan menurut Bapak HH (45) sebagai berikut: 


\begin{abstract}
"...tergantung samo kekerasannyo apo dulu” (wawancara tanggal 15 April 2016)

Berdasarkan hasil wawancara dari masyarakat bahwa kekerasan yang sering terjadi pada pria bergaya feminin ini tergantung kekerasannya dan kekerasan juga tidak wajar dilakukan.
\end{abstract}

\section{Peran Ganda}

Peran ganda yang terjadi diskriminasi terhadap pria bergaya feminin dimana memiliki dua peran ganda laki-laki memiliki peran parempuan seperti lemah lembut. Berkaitan dengan hal tersebut disampaikan beberapa pernyataan informan mengenai peran ganda, pernyataan pertama NV (24) sebagai berikut:

“...perkerjaannyo samo cak pekerjaan cewek tapi idaknyo sepenuhnyo cak cewek nian" (wawancara tanggal 26 April 2016)

Kemudian pernyataan yang diungkapkan oleh EKL (27) sebagai berikut:

“..biaso ajo pekerjaanyo tu” (wawancara tanggal 11 April 2016)

Sedangkan pernyataan yang sama diungkapkan oleh UJ (24) selaku pria bergaya feminin sebagai berikut:

"...pekerjaannyo tu cak cewek" (wawancara tanggal 27 April 2016)

Kemudian pernyataan yang diungkapan oleh TN (24) sebagai berikut:

"...intinyo pekerjaan pria bergaya feminin kadang banyak cak cowok beneran dio dak tau dandak endak yang berat dan yang panas" (wawancara tanggal 27 April 2016)

Berdasarkan hasil wawancara dari pria bergaya feminin ini peran ganda yang dimiliki pria bergaya feminine adalah "sifat" feminitas yang dianggap tidak sesuai untuk tubuh laki-laki.
Sedangkan menurut responden masyarakat mengenai peran ganda yang dimiliki pria bergaya feminin, pernyataan pertama disampaikan oleh Bapak $\mathrm{MH}$ (40) sebagai berikut:

\section{"...biasanya lebih condong} keperkerjaan wanita seperti disalon, pekerjaan yang tidak disenangi masyarakat dan juga saya adalah pekerjaan ganda, yamg dilakukan dengan sesame jenis biasanya penyimpangan seksual" (wawancara tanggal 17 April 2016)

Kemudian pernyataan yang diungkapakan Bapak LH (35) sebagai berikut:

“...tengok ajo cakmano pekerjaannyo seandainyo itu elok dan masyarakat jugo menerimanyo ku raso sah-sah ajo contohnyo cak disalon" (wawancara tanggal 17 April 2016)

Sedangkan pernyataan Bapak SR (27) sebagai berikut:

“...biasonyo pekerjaan pria bergaya feminin ko agak menyimpang karno idak dianggap sesuai dengan ajaran yang ado dimasyarakat", (wawancara tanggal 17 April 2016)

Kemudian menurut Bapak HH (45) sebagai berikut:

“...pekerjaan pria bergaya feminin ko ado baik nyo ado idak nyo, tetapi biasonyo perkerjaannyo disalon tulah" (wawancara tanggal 19 April 2016)

Berdasarkan hasil dari beberapa pernyataan dengan masyarakat bahwa peran ganda pada pria bergaya feminin ini baik asalkan jangan menyimpang dan peran gandanya juga kebanyakannya melakukan pekerjaan perempuan seperti di salon. 


\section{Pembahasan}

Landasan dalam penelitian ini peneliti menggunakan teori Diskriminasi menurut Vaughan dan Hogg (2005). Diskriminasi merupakan perbedaan perlakuan yang tidak adil dan tidak seimbang yang dilakukan untuk membedakan perorangan atau kelompok. Yang biasanya bersifat kategori kesukubangsaan, agama, dan ras. Hasil penelitian ini menunjukan bahwa diskriminasi terhadap pria bergaya feminin dilakukan lima cara yaitu:

\section{Marjinalisasi}

Dari hasil wawancara peneliti dengan informan dapat dijelaskan bahwa proses marjinalisasi atau penyingkiran yang juga sering terjadi pada pria bergaya feminin ini akibat perilaku pria bergaya feminin ini yang tidak sesuai dengan masyarakat seperti melakukan suatu musyawarah pedesaan atau RT pria bergaya feminin ini selalu tidak dihiraukan atau tidak dianggap kalau dia wajib memberikan kritikan atau saran dalam musyawarah tersebut.Adapun beberapa masyarakat mempercayai tetapi tidak untuk mempercayai atau meyakini pendapat pria bergaya feminin ini. Masyarakat juga selalu memperlakukan pria bergaya feminin ini tidak wajar dan mengatakan pria bergaya feminin ini tidak pantas hidup dan sebagainya, adapun masyarakat mengatakan bahwa pria bergaya feminin ini akibat perngaruh lingkungan karena telalu banyak bergaul dengan lawan jenis. Dalam halnya pria bergaya feminin ini juga diasingkan atau dibedakan pada saat berkumpul bersama laki-laki karena meraka tidak menyakini atau berkata tidak pantas pria bergabung bersama laki-laki akibat pria bergaya feminin ini kemayu atau bergaya seperti perempuan. Adapun masyarakat selalu memperhatikan aktifitas pria bergaya feminin itu sehingga muncul rasa kesal dan tidak suka karena pria bergaya feminin ini bersifat tidak sesuai dengan jenis kelamin layaknya seorang laki-laki, maka dari itu terjadinya penyingkiran terhadap pria bergaya feminin di kelurahan Sawah Lebar jalan Kemang Manis 4 RT 7 RW 2 kota Bengkulu.

\section{Subordinasi}

Subordinasi juga termasuk bagian dari diskriminasi, dalam penelitian ini subordinasi adanya masyarakat tidak mempercayai apa yang dilakukan pria bergaya feminin dalam mengikuti kegiatan yang ada di Kemang Manis 4 RT 7 RW 2 kota Bengkulu, karena masyarakat melihat dari perilaku dan cara pria bergaya feminin yang dianggap menyimpang. Penyimpangan yang terjadi pada pria bergaya feminin di kelurahan Sawah Lebar jalan Kemang Manis 4 RT 7 RW 2 kota Bengkulu ini, dilihat dari pekerjaan pria bergaya feminin ini yang sering sekali melakukan pekerjaan yang tidak sesuai dengan jenis kelamin. Masih sedikitnya pria bergaya feminin di Kemang Manis 4 RT 7 RW 2 pria bergaya feminin yang bekerja pada posisi atau peran pengambil keputusan atau penentu kebijakan dibanding lakilaki.

Dalam pekerjaan yang dilakukan oleh pria bergaya feminin, selalu menghasilkan upah atau gaji lebih rendah dibandingkan pria yang sewajarnya, walaupun pekerjaan pria bergaya feminin itu lebih baik dibandingkan dari laki-laki yang sewajarnya.

Pria bergaya feminine ini seringkali melakukan hal-hal seperti layaknya seorang perempuan, dan melakukan pekerjaan perempuan, pria bergaya feminin ini terkadang membuat masyarakat kesal dan membeci akibat ulah dan perilaku pria bergaya feminin ini, adapun kekesalan masyarakat itu memang sengaja dibuat oleh pria bergaya feminin ini karena mereka tidak senag perlakuan masyarakat terhadap pria bergaya feminin ini. Misalnya seperti pada saat pria bergaya feminin ini lewat 
depan rumah masyarakat mereka melakukan hal yang tidak wajar bagi masyarakat seperti memaki alat kecantikan perempuan, dari itulah rasa kesal dan membuat masyarakat berkata kalau pria bergaya feminin ini menyimpang dari ajaran dan normanorma yang ada. Bagi pria bergaya feminin masyarakat menilai mereka seperti itu wajar karena mereka sadar apa yang mereka lakukan tidak sesuai dengan ajaran dan perilaku seorang laki-laki dan menyimpang tetapi pria bergaya feminin ini merasa nyaman dengan apa yang mereka lakukan dan mereka perbuat seperti layaknya seorang perempuan walaupun mayarakat berpikir itu penyimpangan.

\section{Streotip Negatif}

Streotif negatif merupakan pelabelan terhadap pria bergaya feminin dikalangan masyarakat yang tidak baik, dalam pelabelan tersebut pria bergaya feminin sealalu rendah dimata masyarakat disekitar pria bergaya feminin. Adapun pelabelan dari masyarakat terhadap pria bergaya feminin ini mereka melihat dari pekerjaan seorang pria bergaya feminin yang tidak baik. Terkadang masyarakat melihat pria bergaya feminin ini mereka pulang bekerja larut malam masyarakat berpikir kalau pekerjaan pria bergaya feminin ini tidak baik. Pria bergaya feminine ini pun bias seperti layaknya seorang laki-laki maupun layaknya seorang perempuan.

Sedangkan bagi pria bergaya feminin ini masyarakat menilai seperti itu mereka tidak merasa terganggu dan mereka pun tidak terlalu menghiraukan apa yang dilakukan masyarakat terhadap mereka. Pria bergaya feminin ini selalu tidak menghiraukan apa yang masyarakat lakukan terhadap mereka karena mereka merasa kalau mereka tidak mengganggu masyarakat hanya masyarakat saja yang tidak menyukai pria bergaya feminin.
Masalah berpikir negatif masyarakat terhadap pria bergaya feminin bagi pria bergaya feminin mereka merasa tidak ada merugikan seorang pria bergaya feminin karena mereka cuma bisa menilai apa yang mereka lihat saja. Dalam hal itu seorang pria bergaya feminin ini mengartikan apa yang dikatakan masyarakat terhadap mereka yang selalu negatif pria bergaya feminin ini melakukan sebaliknya dan membuktikan perkataan yang masyarakat berpikir negatif tersebut yang tidak baik terhadap pria bergaya feminin ini.

\section{Kekerasan}

Kekerasan merupakan perilaku yang tidak baik,tetapi kekerasan terhadap pria bergaya feminin ini terjadi adanya akibat ulah dan perilaku pria bergaya feminin itu sendiri, kekerasan yang terjadi memlalui kekerasan fisik dan non fisik ini kerap terjadi pada pria bergaya feminin.

Kekerasan non fisik yang sering terjadi pada pria bergaya feminin ini seperti perkataan masyarakat mengenai cara dan perilaku mereka yang seperti perempuan, masyarakat pun sering mengatakan bahwa seotang pria bergaya feminin ini tidak baik dan tidak pantas ada karena itu sudah menyalahi hukum Islam yang tidak harus terjadi di muka bumi ini. Sedangkan seorang pria bergaya feminin ini tidak merasa melakukan kesalahan karena mereka tau apa yang harus mereka lakukan, masyarakat melakukan kekerasan seperti itu karena mereka tidak menyukai seorang pria bergaya feminin ini. Adapun kekerasan yang non fisik yang terjadi di Kemang Manis 4 RT 7 RW 2 Kota Bengkulu ini, pada saat pria bergaya feminin ini lewat depan rumah masyarakat, masyarakat selalu mengatakan kalau mereka salah arah dan perkataan yang tidak baik seperti lakilaki tapi bergaya perempuan dan berperilaku tidak sesuai dengan jenis 
kelamin yang mereka punya. Dalam hal itu pria bergaya feminin ini tidak merasa dan mereka tidak menanggapi apa yang dikatakan masyarakat tentang mereka karena mereka mempunyai dan melakukan hal terasebut seperti berperilaku perempuan mereka mempunyai pendirrian sendiri tanpa menghiraukan perkataan dan kekerasan non fisik terhadap mereka.Adapun Kekerasan fisik yang terjadi pada pria bergaya feminin di kelurahan Sawah Lebar jalan Kemang manis 4 RT 7 RW 2, kekerasan fisik yang terjadi yaitu seorang pria bergaya feminine melakukan kesalahan yang tidak terlalu fatal namun seorang pria bergaya feminin ini menerima kekerasan dengan cara memasukan seorang pria bergaya feminin ini kedalam ember lalu disiram dengan air yang kotor, kekerasan ini tidak sewajarnya dilakuan.

Seorang pria bergaya feminin ini cuma bisa diam dan tidak melakukan apapun, kekerasan fisik yang juga terjadi kepada pria bergaya feminin yang disuruh seorang kerabatnya berlari sejauh 5 meter pada malam hari. Hal tersebut tidak membuat seorang pria bergaya feminin ini untuk bertindak dengan alasan kalau seorang pria bergaya feminin ini menyukai salah orang yang melakukan kekerasan terhadap dia.

\section{Peran Ganda}

Peran ganda merrupakan dimana suatu pekerjaan yang dilakukan pria bergaya feminin ini yang tidak membedakan dan memperfokuskan dia didalam suatu pekerjaan yang sering dilakukannya. Namun perkerjaan pria bergaya feminin ini yang seringkali jadi bahan perkataan dimana pekerjaannya juga membuat kapan dan dimana dia berkerja.

Perkerjaan seorang pria bergaya feminin ini tidak terfokus pekerjaan yang tidak sesuai dengan jenis kelamin dan perilaku yang dia miliki, dan peran yang sering dia lakukan pun tidak menentu karena dia bisa menjadi perempuan dan bisa juga berkerja seperti laki-laki seperti dia pada saat kejadian kebakaran disalah satu kontrakan di Kemang Manis 4 RT 7 RW 2 kota Bengkulu disana seorang pria bergaya feminin ini melakukan pekerjaan seorang laki-laki yang lainnya sedangkan masyarakat tidak mempercayai apa yang dilakukan seorang pria bergaya feminin ini, karena mereka menilai kalau seorang pria bergaya feminin ini tidak bisa melakukan pekerjaan selayaknya seorang laki-laki yang sebenarnya. Dan seorang pria bergaya feminin ini juga bisa melakukan pekerjaan seorang perempuan yang cukup pandai seperti melakukan perkerjaan rumah dan berhias seperti perempuan.

Pria bergaya feminine ini juga seringkali membuat masyarakat tidak menyukai dengan pekerjaan mereka seperti itu, namun dari seorang pria bergaya feminine ini juga mengatakan bahwa mereka sadar apa yang mereka lakukan sehingga mereka melakukan hal tersebut dan mereka juga merasa senang dengan peran ganda yang bisa mereka lakukan tanpa ada yang merasa dirugikan dengaaa lakukan tersebut.

Dalam hal itu pria bergaya feminine ini juga merasa salah apa yang mereka lakukan karena mereka terlalu banyak membuat masyarakat benci dan tidak menyukai mereka seperti itu, mereka pun tidak tau mengapa mereka seperti itu dan bisa kapan dia menjadi laki-laki dan kapan mereka menjadi seorang perempuan. Pria bergaya feminine ini juga ingin sma seperti masyarakat lainnya yang terfokus melakukan hal hanya satu jenis sperti laki-laki sewajarnya dan perempuan yang sewajarnya, tetapi mereka juga tidak mengetahui mengapa mereka ditakdirkan seperti itu. 
PENUTUP

Kesimpulan

Berikut merupakan kesimpulan dari penelitian ini:

1. Marjinalisasi

Masyarakat cenderung tidak banyak menyukai dan membedakan perlakuan terhadap pria bergaya feminin. Hal ini terjadi karena adanya anggapan bahwa feminitas pada tubuh laki-laki merupakan bentuk penyimpangan. Namun begitu, masyarakat masih menerima pria bergaya feminine untuk tinggal di wilayah mereka. Pada sisi pria feminine, mereka cenderung cuek dan tidak mempermasalahkan anggapan maupun perlakuan masyarakat terhadap mereka.

2. Subordinasi

Dalam konteks kepemimpinan, masyarakat tidak menyakini atau memberikan dukungan atas keikutsertaan pria bergaya feminine dalam suatu organisasi, apalagi untuk menjadi pemimpin.

3. Streotip Negatif

Streotip negatif yang diberikan terutama berkaitan dengan pelabelan negative pria bergaya feminine yang "mengingkari" jenis kelamin lahiriah mereka. Namun begitu, pria-pria bergaya feminine ini bersikap cuek dan memilih untuk tidak menghiraukan pendapat masyarakat.

4. Kekerasan

Kekerasan yang terjadi pada pria bergaya feminin ini tidak mesti terjadi dan kekerasan yang sering terjadi masyarakat juga ingin mengetahui permasalahannya dan siapa yang membuat permasalahan sehingga kekerasan itu terjadi. Kekerasan pun tidak sewajanya terjadi kerena bagaimana pun pria bergaya feminin ini sama seperti masyarakat lainnya.

\section{Peran Ganda}

Pria bergaya feminin cenderung melakukan pekerjaan perempuan dan terkadang pria bergaya feminin ini pun melakukan pekerjaan lai-laki. Masyarakat pun banyak mengatakan pria bergaya feminin ini lebih banyak bekerja seperti lawan jenis.

\section{Saran}

Berdasarkan kesimpulan diatas, maka saran untuk masyarakat kelurahan Sawah Lebar jalan Kemang Manis 4 RT 7 RW 2 kota Bengkulu adalah:

1. Agar lebih menghormati setiap pilihan hidup anggota masyarakat

2. Menghargai sesama tanpa ada yang merasa dibedakan atau diasingkan dengan masyarakat lainnya.

\section{DAFTAR PUSTAKA}

Fultoni. (2009). Diskriminasi Gender Perempuan. Bandung: Pustaka Pelajar

Miles, Matthew B \& A. M. Huberman. (1994). Qualitative Data Analyis. USA: Sage Publication.

Moleong. (2007). Metode Penelitian Kualitatif. Bandung: Remaja Rosdakarya.

Perdana Putri. (2012). Diskriminasi Terhadap Waria Jakarta. Skripsi. Univeristas Indonesia. Jakarta.

Sugiyono. (2014). Pengantar Psikologi. Jakarta: Bulan Bintang.

Vaughan, Graham M \& Michael A Hogg. (2005). Social Psychology. Australia: Pearson Australia.

Sumber online:

Anna, Lusia Kus. (2016). "Laki-laki Kok Kemayu". http://health.kompas.com/read/20 16/01/30/130000023/Lakilaki.Kok.Kemayu. diakses Selasa 10 Mei 2016 pukul 10.12 WIB 